\title{
INTELLIGENCE, PHYSIQUE, AND FAMILY SIZE
}

\author{
BY \\ J. A. SCOTT \\ Principal School Medical Officer, London County Council
}

In his fifth Reith lecture on December 13, 1959, Professor P. B. Medawar, dealing with Intelligence and Fertility, made the three following statements: Professor Medawar, dealing with Intelligence and Fertility, made the three following statements:

(i) Children who belong to small families are known to do better in intelligence tests than children of larger families;

(ii) On the whole, children of large families are not quite so tall, at any given age of childhood, as the children of smaller families;

(iii) So far as our meagre evidence goes, there is some small but definite connexion between the intelligence of children and their size at any given age of childhood.

The first statement is supported by Burt (1946), the Scottish 1947 Mental Survey $(1953,1958)$ and Vernon (1960), the second by Keddie (1958) and Scott (1961), and the third, so far as height is concerned, was put forward as long ago as 1905 , by Dr. James Kerr (1906) the first school medical officer for London, and received further support from Burt (1917). The Reith lectures were given in 1959 at a time when the data collected for a survey of heights and weights, etc., of school pupils in London were being analysed. As these data included a crude indication of family size it was thought that, if it were feasible to link the survey data in a limited way with a measure of intelligence as assessed by the verbal reasoning test at the junior school-leaving examination, it might be possible to confirm or deny the statements and add to the "meagre evidence".

\section{METHOD}

In the height and weight survey of 1959, the results of which have already been published (Scott, 1961), there were about 2,700 boys and 2,500 girls aged 10 and 11 . The methods of sample selection were fully described in the report thereon, but briefly these pupils were a cross-section of children attending ordinary day schools in London. It was found possible to marry the verbal reasoning scores with the height and weight measurements of four main groups of children as follows:

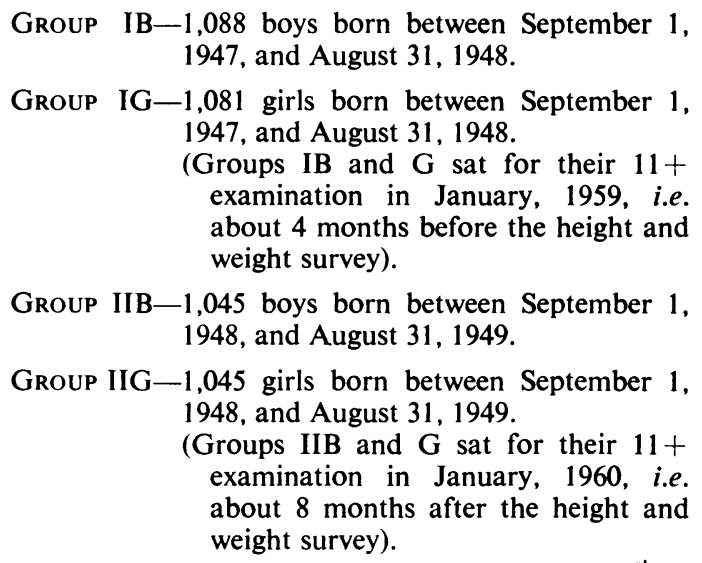

The equality of the numbers in Groups IIB and IIG was a coincidence. The verbal reasoning test used in 1959 was the Moray House Test 61, and in 1960 the National Foundation for Educational Research Test 9B. Both these tests had a maximum raw score of 100 , but this raw score was standardized for age and converted* to a "normal" distribution with a theoretical mean of 100 and a standard deviation of 15 .

Because of the difference in timing it was not possible to find verbal reasoning scores for all the children measured in the appropriate age range. Some children with a low I.Q. did not sit for the

* Conversion of the horizontal distribution of raw scores to a normal distribution is standard practice with verbal reasoning tests. For a full description of the technique see Lawley (1950). 
examination and other children who were measured for height and weight had moved away from London before the test. This lack of complete accord is an inevitable consequence of trying to utilize for one purpose data collected for another. There is, however, no reason to assume any marked difference in the children who removed from London and those who stayed and for whom it was possible to relate physical measurements with verbal reasoning scores.

There was yet another difficulty in relation to timing. As the children in the groups were not all weighed and measured at the same age there are minor differences in the mean ages, both between the groups and between sub-groups, when they are divided, for example, by family size. In the main, the random selection for the height and weight survey yielded ages of the same order, but where any difference is likely to give rise to bias this is mentioned. The exact ages at the time of measurement were calculated using the Pearl and Miner table of elapsed time. By using the standardized score as the measure of intelligence, full allowance was made for varying age at the time of the verbal reasoning test.

One last qualification relates to the assessment of family size. The children concerned were asked in effect how many siblings they had at school and not yet at school. All tables, therefore, quote numbers of children rather than size of family and these numbers could include cousins and other children living under the same roof or exclude older siblings who had left school. No information was collected about the birth order of the children. These data are therefore less precise than those relating to physique and intelligence.

The analyses were made using conventional punched card techniques, but the Council's computer division assisted with some of the more arduous of the statistical calculations.

\section{RESULTS}

Table I gives the means and standard errors of the height, weight, and standardized score for each of the four main groups, and of sub-divisions classified according to the number of children in the family.

TABLE I

MEAN HEIGHT, WEIGHT, AND STANDARDIZED SCORE, BY SEX, YEAR OF EXAMINATION, AND FAMILY SIZE

\begin{tabular}{|c|c|c|c|c|c|c|c|}
\hline \multirow{2}{*}{\multicolumn{2}{|c|}{ Group }} & \multirow{3}{*}{$\begin{array}{c}\begin{array}{c}\text { Family Size } \\
\text { (No. of } \\
\text { Children } \\
\text { in Family) }\end{array} \\
1 \\
2 \\
3 \\
4 \\
5 \text { or More }\end{array}$} & \multirow{3}{*}{$\begin{array}{c}\begin{array}{c}\text { No. of } \\
\text { Children } \\
\text { in Class }\end{array} \\
336 \\
399 \\
202 \\
79 \\
72\end{array}$} & \multirow{3}{*}{$\begin{array}{c}\begin{array}{c}\text { Age at } \\
\text { Measure- } \\
\text { ment } \\
\text { (yrs) }\end{array} \\
11 \cdot 25 \\
11 \cdot 26 \\
11.25 \\
11.24 \\
11.27\end{array}$} & \multicolumn{3}{|c|}{ Mean } \\
\hline & & & & & Height (cm.) & Weight (kg.) & $\begin{array}{l}\text { Standardized } \\
\text { Score }\end{array}$ \\
\hline \multirow{4}{*}{$\begin{array}{c}\text { Junior Leaving } \\
(11+) \underset{\text { Examination }}{\text { Examg }}\end{array}$} & \multirow[t]{2}{*}{$\begin{array}{l}\text { Boys } \\
\text { I B }\end{array}$} & & & & $\begin{array}{l}144 \cdot 2 \pm \cdot 37 \\
143.4 \pm \\
142.4 \pm \\
142.8 \\
142.76 \\
140 \cdot 2 \pm .80\end{array}$ & $\begin{array}{ll}37 \cdot 01 \pm & \cdot 36 \\
35 \cdot 23 \pm & 33 \\
34 \cdot 13 \pm & .46 \\
34 \cdot 63 \pm & 74 \\
32 \cdot 47 \pm & 78\end{array}$ & $\begin{array}{l}99 \cdot 9 \pm .83 \\
99 \cdot 1 \pm .76 \\
97 \cdot 5 \pm 1.02 \\
96 \cdot 5 \pm 1 \cdot 71 \\
93 \cdot 1 \pm 1 \cdot 79\end{array}$ \\
\hline & & All & 1,088 & $11 \cdot 25$ & $143 \cdot 2 \pm \cdot 20$ & $35 \cdot 35 \pm \cdot 20$ & $98 \cdot 5 \pm \cdot 46$ \\
\hline & \multirow[t]{2}{*}{$\underset{\text { I G }}{\text { Girls }}$} & $\begin{array}{c}1 \\
2 \\
3 \\
4 \\
5 \text { or More }\end{array}$ & $\begin{array}{r}307 \\
412 \\
196 \\
106 \\
60\end{array}$ & $\begin{array}{l}11 \cdot 26 \\
11 \cdot 23 \\
11 \cdot 24 \\
11 \cdot 25 \\
11 \cdot 23\end{array}$ & $\begin{array}{l}145 \cdot 3 \pm .43 \\
144.8 \pm \\
143.9 \pm \\
142.54 \\
142.7 \pm \\
140.4 \pm .98\end{array}$ & $\begin{array}{l}38 \cdot 67 \pm .45 \\
37 \cdot 08 \pm .39 \\
36 \cdot 15 \pm .56 \\
34 \cdot 62 \pm .77 \\
32 \cdot 76 \pm 1 \cdot 02\end{array}$ & $\begin{array}{r}101 \cdot 8 \pm .82 \\
102.4 \pm .71 \\
99 \cdot 5 \pm 1.03 \\
97.8 \pm 1.40 \\
93.9 \pm 1.86\end{array}$ \\
\hline & & All & 1,081 & $11 \cdot 24$ & $144 \cdot 3 \pm \cdot 23$ & $36 \cdot 88 \pm \cdot 24$ & $100 \cdot 8 \pm \cdot 44$ \\
\hline \multirow{4}{*}{$\begin{array}{c}\text { Junior Leaving } \\
(11+) \text { Examination } \\
\text { in } 1960\end{array}$} & \multirow[t]{2}{*}{$\begin{array}{l}\text { Boys } \\
\text { II B }\end{array}$} & $\begin{array}{c}1 \\
2 \\
3 \\
4 \\
5 \text { or More }\end{array}$ & $\begin{array}{r}243 \\
425 \\
201 \\
98 \\
78\end{array}$ & $\begin{array}{l}10 \cdot 26 \\
10 \cdot 24 \\
10 \cdot 25 \\
10 \cdot 24 \\
10 \cdot 26\end{array}$ & $\begin{array}{l}139 \cdot 0 \pm \cdot 41 \\
138 \cdot 7 \pm \cdot 31 \\
138 \cdot 0 \pm .46 \\
136 \cdot 8 \pm \cdot 65 \\
136 \cdot 3 \pm \cdot 71\end{array}$ & $\begin{array}{ll}34 \cdot 04 \pm & \cdot 39 \\
32 \cdot 56 \pm & .30 \\
31 \cdot 52 \pm & .43 \\
31 \cdot 24 \pm & .62 \\
31 \cdot 04 \pm & .69\end{array}$ & $\begin{array}{r}102 \cdot 8 \pm .96 \\
102 \cdot 5 \pm .73 \\
101.9 \pm 1.01 \\
99 \cdot 2 \pm 1.51 \\
93.9 \pm 1.70\end{array}$ \\
\hline & & All & 1,045 & $10 \cdot 25$ & $138 \cdot 3 \pm \cdot 20$ & $32 \cdot 47 \pm \cdot 19$ & $101 \cdot 5 \pm \cdot 46$ \\
\hline & \multirow[t]{2}{*}{$\begin{array}{l}\text { Girls } \\
\text { II G }\end{array}$} & $\begin{array}{c}1 \\
2 \\
3 \\
4 \\
5 \text { or More }\end{array}$ & $\begin{array}{r}244 \\
396 \\
213 \\
107 \\
85\end{array}$ & $\begin{array}{l}10 \cdot 28 \\
10 \cdot 23 \\
10 \cdot 26 \\
10 \cdot 26 \\
10 \cdot 26\end{array}$ & 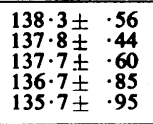 & 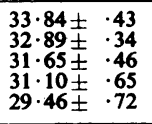 & $\begin{array}{r}106.0 \pm .96 \\
104.8 \pm .75 \\
102.9 \pm 1.03 \\
99 \cdot 5 \pm 1.45 \\
95 \cdot 5 \pm 1.66\end{array}$ \\
\hline & & All & 1,045 & $10 \cdot 25$ & $137 \cdot 6 \pm \cdot 27$ & $32 \cdot 40 \pm \cdot 21$ & $103 \cdot 4 \pm .46$ \\
\hline
\end{tabular}

As the mean standardized score of three of the four groups is significantly different (more than \pm twice the standard error) from the theoretical mean of 100 , the observed parameters of the groups were used in subsequent assessments of significance. 
The difference in the mean age at weighing and measuring between any two classes in a group never exceeded 0.05 years (under 3 weeks) and was usually much less. There is an age difference of a year in the ages of measurement between Groups I and II, but this does not affect comparisons within groups.

In both 1959 and 1960 the mean standardized scores of the girls were higher than those of the boys both in total and for each family size. The differences in the mean scores for the sexes as a whole are statistically significant, but such differences are found in the generality of London children and have also been observed nationally (National Foundation for Educational Research, 1957).

Table I also shows that, as the number of children in the family increases, mean height, weight, and intelligence scores tend to decrease, the only exceptions being in the intelligence score of 2-child families in Group IG and the height and weight of 4-child families in Group IB. The means of any family size are generally not significantly different from those of the adjacent class in the same group, but significant differences usually appear when alternate classes are compared. The gradient in the mean physique and intelligence with family size offers yet further evidence that children who belong to small families tend to do better in intelligence tests than children from larger families, and that children from large families are not so tall (or so heavy) at any given age as those from small families.

The relationship between height, weight, intelligence, and family size apparent in Table I has been expressed in terms of correlation coefficients which are set out in Table IIA (the logarithms of numbers of children in family were used to reduce the skewness of the original frequency distribution).

These correlation coefficients were based on the attributes of individual children, and all the coefficients (except that for family size and height of Group IIG) are significant (at the 1 per cent. level): had they been based on the group means of Table I they would have been higher though not necessarily more significant. As it is, they confirm that, despite the considerable variation of these attributes among children, there is a marked tendency for height, weight, and intelligence, particularly the first two, to rise and fall together, and for all three to vary inversely with family size.

The relationship of intelligence to physique cannot be assessed from Tables I and IIA because of the uncertainty of the effect of differences in the numbers of children in family. As a partial step towards elimination of this factor, correlation coefficients of height, weight, and intelligence have been calculated (on the same basis as for Table IIA) but only for the
TABLE IIA

CORRELATION COEFFICIENTS-ALL CHILDREN

\begin{tabular}{|c|c|c|c|c|c|c|}
\hline Group & $\begin{array}{c}\text { No. of } \\
\text { Pairs of } \\
\text { Observations }\end{array}$ & Variable & Height & Weight & $\begin{array}{c}\text { Family } \\
\text { Size } \\
\text { (log. } \\
\text { of) }\end{array}$ & $\begin{array}{c}\text { Intelli- } \\
\text { gence }\end{array}$ \\
\hline $\begin{array}{l}\text { I } \mathbf{B} \\
\text { I } \\
\text { II } \\
\text { II } \\
\mathbf{~ G}\end{array}$ & $\begin{array}{l}1,088 \\
1,081 \\
1,045 \\
1,045\end{array}$ & Height & E & $\begin{array}{l}.70 \\
.67 \\
.67 \\
.61\end{array}$ & $\begin{array}{l}-\cdot 15 \\
-\cdot 15 \\
-\cdot 12 \\
-.03 *\end{array}$ & $\begin{array}{l}\cdot 21 \\
\cdot 21 \\
\cdot 14 \\
\cdot 36\end{array}$ \\
\hline $\begin{array}{l}\text { I B } \\
\text { I G } \\
\text { II } \\
\text { II G }\end{array}$ & $\begin{array}{l}1,088 \\
1,081 \\
1,045 \\
1,045\end{array}$ & Weight & $\begin{array}{l}.70 \\
.67 \\
.67 \\
.61\end{array}$ & E & $\begin{array}{l}-\cdot 20 \\
-\cdot 20 \\
-\cdot 18 \\
-\cdot 18\end{array}$ & $\begin{array}{l}\cdot 10 \\
\cdot 15 \\
\cdot 09 \\
\cdot 18\end{array}$ \\
\hline $\begin{array}{l}\text { I } \mathbf{~ B} \\
\text { I G } \\
\text { II } \mathbf{~ B ~} \\
\text { II } \mathbf{G}\end{array}$ & $\begin{array}{l}1,088 \\
1,081 \\
1,045 \\
1,045\end{array}$ & $\begin{array}{l}\text { Family } \\
\text { Size } \\
\text { (log. of) }\end{array}$ & $\begin{array}{l}-\cdot 15 \\
-.15 \\
-\cdot 12 \\
-.03 *\end{array}$ & $\begin{array}{l}-\cdot 20 \\
-\cdot 20 \\
-\cdot 18 \\
-\cdot 18\end{array}$ & E & $\begin{array}{l}-\cdot 11 \\
-\cdot 12 \\
-\cdot 12 \\
-\cdot 17\end{array}$ \\
\hline $\begin{array}{l}\text { I } \mathbf{B} \\
\text { I } \\
\text { II } \\
\text { II } \\
\mathbf{G}\end{array}$ & $\begin{array}{l}1,088 \\
1,081 \\
1,045 \\
1,045\end{array}$ & $\begin{array}{l}\text { Intelli- } \\
\text { gence }\end{array}$ & $\begin{array}{l}\cdot 21 \\
\cdot 21 \\
\cdot 14 \\
\cdot 36\end{array}$ & $\begin{array}{l}\cdot 10 \\
\cdot 15 \\
\cdot 09 \\
\cdot 18\end{array}$ & $\begin{array}{l}-\cdot 11 \\
-\cdot 12 \\
-\cdot 12 \\
-\cdot 17\end{array}$ & E \\
\hline
\end{tabular}

* Not significant.

TABLE IIB

CORRELATION COEFFICIENTS-CHILDREN FROM 1-CHILD AND 2-CHILD FAMILIES

\begin{tabular}{|c|c|c|c|c|c|}
\hline Group & $\begin{array}{l}\text { No. of Pairs } \\
\text { of } \\
\text { Observations }\end{array}$ & Variable & Height & Weight & $\begin{array}{l}\text { Intelli- } \\
\text { gence }\end{array}$ \\
\hline $\begin{array}{l}\text { I } \mathbf{~ B} \\
\text { I I G } \\
\text { II } \\
\text { II } \\
\mathbf{~ G}\end{array}$ & $\begin{array}{l}735 \\
719 \\
668 \\
640\end{array}$ & Height & $\bar{z}$ & $\begin{array}{l}.68 \\
.64 \\
.67 \\
.63\end{array}$ & $\begin{array}{l}\cdot 22 \\
\cdot 17 \\
\cdot 11 \\
\cdot 20\end{array}$ \\
\hline $\begin{array}{r}\text { I B } \\
\text { I } \\
\text { II } \\
\text { II } \\
\mathbf{~ G}\end{array}$ & $\begin{array}{l}735 \\
719 \\
668 \\
640\end{array}$ & Weight & $\begin{array}{l}.68 \\
.64 \\
.67 \\
.63\end{array}$ & $\bar{z}$ & $\begin{array}{l}.09 * \\
.09 * \\
.10 \\
.09\end{array}$ \\
\hline$\underset{\text { II I }}{\text { I }} \underset{\mathbf{G}}{\mathbf{G}}$ & $\begin{array}{l}735 \\
719 \\
668 \\
640\end{array}$ & Intelligence & $\begin{array}{l}\cdot 22 \\
\cdot 17 \\
\cdot 11 \\
\cdot 20\end{array}$ & $\begin{array}{l}.09^{*} \\
.09^{*} \\
\cdot 10 \\
.09^{*}\end{array}$ & 二 \\
\hline
\end{tabular}

* Significant only at 5 per cent. level.

1-child and 2-child families combined-the measures of these two sizes of family are not markedly dissimilar and in any case there is a wide and overlapping gradation of physique in each type of family. The results are shown in Table IIB.

With smaller numbers of children in the group the level of significance is altered, but all the coefficients are significant at the 5 per cent. level and, except for weight and intelligence, at the 1 per cent. level also. Thus partial removal of the effect of family size from the association of this factor with physique leaves a relationship between height and intelligence of a similar order to that of Table IIA and a slightly lessened correlation of weight with intelligence. The question arises whether height or weight is a better 
indicator of size when considered in relation to intelligence and family size. Either would do because of their correlation, but as Tanner (1961) points out "Even failure to gain weight or actual loss of weight in an older child may signify little except a better attention to diet and exercise, whereas failure to gain height or muscle would call for immediate investigation". In Table III, therefore, height has been taken as the indicator of size in relation to the intelligence scores of 1-child and 2-child families combined. The aggregation of these families provided more adequate numbers over the whole range of standardized scores and there was only one significant difference (Group IB) in height between these two classes. (In the original survey of heights and weights from which this sub-sample was drawn there were no significant differences at these ages in the heights of children in these two family classes.)

Table III shows clearly an increasing average height with increasing intelligence, divorced from the major effects of family size. As in Table I class means do not differ significantly from adjoining classes in the same group, but except in Group IIB alternate classes do differ significantly.

It should be borne in mind that pupils were measured during the summer term of 1959 and the mean heights shown were not those that obtained when the intelligence tests were taken. In Group I the children were probably shorter by at least 4-months' growth and in Group II they were anything up to 8-months' growth taller. At this age boys are gaining on average about $5 \mathrm{~cm}$. a year and girls $7 \mathrm{~cm}$., although individual children vary enormously in the timing of their adolescent spurt. However, this does not affect the validity of the gradient of higher intelligence with greater height within the four groups.

Table III has shown that intelligence is related to height, and Table I that intelligence is related to family size and incidentally that height is also related to family size. The question arises which of these two, height or family size, has the greater influence on intelligence. In an attempt to find an answer the data of Group IIG (chosen at random) have been set out in Table IV by height and family size to show the mean intelligence test score for each combination of attributes. Height was not measured at a uniform age but standardization is not possible because of the widely differing rates of growth of adolescent children; were it possible it would have had the effect of transferring a few children from one height column to an adjoining one, but it is doubtful if the comparison would be seriously affected.

Table IV shows a tendency for intelligence both to increase with height and to lessen as family size increases. The maximum difference in mean intelligence scores-that between the shortest children of the largest families and the tallest children of the

TABLE IV

AVERAGE VERBAL REASONING STANDARDIZED SCORES BY HEIGHT AND FAMILY SIZE-DATA OF GROUP II G (Figures in brackets are the number of children in each class)

\begin{tabular}{|c|c|c|c|c|}
\hline \multirow{2}{*}{ Height (cm.) } & \multicolumn{4}{|c|}{ Number of Children in Family } \\
\hline & 1 & 2 & 3 & 4 and More \\
\hline $\begin{array}{c}\text { Less than } \\
130 \cdot 0\end{array}$ & $\begin{array}{l}96 \cdot 2 \\
(19)\end{array}$ & $\begin{array}{c}101 \cdot 2 \\
(35)\end{array}$ & $\begin{array}{l}97 \cdot 5 \\
(16)\end{array}$ & $\begin{array}{l}94 \cdot 5 \\
(33)\end{array}$ \\
\hline $130 \cdot 0-134 \cdot 9$ & $\begin{array}{c}102 \cdot 1 \\
(58)\end{array}$ & $\begin{array}{c}100 \cdot 4 \\
(88)\end{array}$ & $\begin{array}{c}101 \cdot 4 \\
(52)\end{array}$ & $\begin{array}{l}94 \cdot 1 \\
(55)\end{array}$ \\
\hline $135 \cdot 0-139 \cdot 9$ & $\begin{array}{c}108 \cdot 4 \\
(70)\end{array}$ & $\begin{array}{l}107 \cdot 0 \\
(119)\end{array}$ & $\begin{array}{c}102 \cdot 4 \\
(80)\end{array}$ & $\begin{array}{l}100 \cdot 7 \\
(44)\end{array}$ \\
\hline $140 \cdot 0-144 \cdot 9$ & $\begin{array}{c}108 \cdot 5 \\
(54)\end{array}$ & $\begin{array}{l}106 \cdot 0 \\
(104)\end{array}$ & $\begin{array}{c}105 \cdot 9 \\
(37)\end{array}$ & $\begin{array}{l}99 \cdot 9 \\
(44)\end{array}$ \\
\hline 145 and Over & $\begin{array}{c}108 \cdot 5 \\
(43)\end{array}$ & $\begin{array}{c}107 \cdot 5 \\
(50)\end{array}$ & $\begin{array}{c}106 \cdot 5 \\
(28)\end{array}$ & $\begin{array}{c}102 \cdot 8 \\
(16)\end{array}$ \\
\hline
\end{tabular}

TABLE III

MEAN HEIGHTS* OF CHILDREN FROM 1-CHILD AND 2-CHILD FAMILIES, BY INTELLIGENCE SCORE

\begin{tabular}{|c|c|c|c|c|c|c|c|c|}
\hline \multirow{2}{*}{$\begin{array}{ll}\text { Group . } & \cdots \\
\operatorname{Sex} \quad \cdots & \cdots \\
\end{array}$} & \multicolumn{4}{|c|}{ I } & \multicolumn{4}{|c|}{ II } \\
\hline & \multicolumn{2}{|r|}{ B } & \multicolumn{2}{|r|}{$\mathbf{G}$} & \multicolumn{2}{|r|}{ B } & \multicolumn{2}{|r|}{$\mathbf{G}$} \\
\hline $\begin{array}{c}\text { Verbal } \\
\text { Reasoning } \\
\text { Standardized } \\
\text { Score }\end{array}$ & $\begin{array}{l}\text { No. of } \\
\text { Children }\end{array}$ & Mean Height & $\begin{array}{l}\text { No. of } \\
\text { Children }\end{array}$ & Mean Height & $\begin{array}{l}\text { No. of } \\
\text { Children }\end{array}$ & Mean Height & $\begin{array}{l}\text { No. of } \\
\text { Children }\end{array}$ & Mean Height \\
\hline \multirow[t]{2}{*}{$\begin{array}{r}70-86 \\
87-95 \\
96-104 \\
105-113 \\
114-140\end{array}$} & $\begin{array}{l}151 \\
147 \\
169 \\
142 \\
126\end{array}$ & $\begin{array}{l}141 \cdot 8 \pm \cdot 56 \\
143 \cdot 1 \pm \cdot 56 \\
143 \cdot 9 \pm \cdot 53 \\
144 \cdot 7 \pm \cdot 57 \\
146 \cdot 0 \pm \cdot 61\end{array}$ & $\begin{array}{r}97 \\
142 \\
162 \\
179 \\
139\end{array}$ & $\begin{array}{l}142 \cdot 7 \pm \cdot 75 \\
144 \cdot 1 \pm \cdot 62 \\
145 \cdot 3 \pm \cdot 58 \\
145 \cdot 6 \pm \cdot 55 \\
147 \cdot 1 \pm \cdot 63\end{array}$ & $\begin{array}{r}92 \\
126 \\
157 \\
135 \\
158\end{array}$ & $\begin{array}{l}137 \cdot 5 \pm \cdot 68 \\
138 \cdot 4 \pm \cdot 58 \\
138 \cdot 5 \pm \cdot 52 \\
139 \cdot 5 \pm \cdot 56 \\
139 \cdot 8 \pm \cdot 52\end{array}$ & $\begin{array}{r}59 \\
101 \\
153 \\
137 \\
190\end{array}$ & $\begin{array}{l}134 \cdot 6 \pm \cdot 84 \\
136 \cdot 7 \pm \cdot 64 \\
138 \cdot 1 \pm \cdot 52 \\
138 \cdot 7 \pm \cdot 55 \\
139 \cdot 3 \pm \cdot 47\end{array}$ \\
\hline & 735 & $143 \cdot 8 \pm \cdot 25$ & 719 & $145 \cdot 2 \pm \cdot 28$ & 668 & $138 \cdot 8 \pm \cdot 25$ & 640 & $138 \cdot 0 \pm \cdot 25$ \\
\hline
\end{tabular}

- Standardized for age by simple linear interpolation-Group I B and G $11 \cdot 25$ years and Group II B and G 10.25 years. 
smallest families-is 14 , almost equal to the standard deviation of the normal distribution of intelligence scores. It was not possible to carry out the orthodox analysis of variance on the data of Table IV because the class frequencies were not equal or proportionate, the original survey not having been planned for this purpose. Instead the "approximate analysis" suggested by Yates (1933) was used. The procedure is first to calculate the variance between all classes, second to weight the mean square of the variance within classes by the harmonic mean of the class frequencies and to use the mean square thus derived as the "experimental error" by which to assess the significance of the mean square variance between rows and columns, and third to carry out an analysis of variance on the table in the usual way, treating each mean as if it were the sole entry in its class. The results of these computations are shown in Table V.

\section{TABLE V}

ANALYSIS OF VARIANCE (APPROXIMATE METHOD) OF VERBAL REASONING STANDARDIZED SCORES, BY HEIGHT AND FAMILY SIZE (DATA OF TABLE IV)

\begin{tabular}{|c|c|c|c|}
\hline Source of Variation & $\begin{array}{l}\text { Degrees of } \\
\text { Freedom }\end{array}$ & $\begin{array}{l}\text { Sum of } \\
\text { Squares }\end{array}$ & $\begin{array}{c}\text { Mean } \\
\text { Square }\end{array}$ \\
\hline Between Means of 20 Classes. . & 19 & $408 \cdot 58$ & \\
\hline \begin{tabular}{cccc} 
Between Means of Family Size \\
Classes & $\ldots$ & \multicolumn{3}{c}{} \\
Between & Means & of & Height \\
Classes &.. & $\ldots$ & $\ldots$ \\
Interaction & $\ldots$ & $\ldots$ & $\ldots$
\end{tabular} & $\begin{array}{r}3 \\
4 \\
12\end{array}$ & $\begin{array}{r}245 \cdot 09 \\
127 \cdot 75 \\
35 \cdot 74\end{array}$ & $\begin{array}{r}81 \cdot 70 \\
31 \cdot 94 \\
2 \cdot 98\end{array}$ \\
\hline Experimental Error $\quad \ldots \quad \ldots$ & 1,025 & & $5 \cdot 15$ \\
\hline
\end{tabular}

The ratio of the mean squares between family size classes and height classes to the mean squares of experimental error are both significant, but the variance is greater between family size classes than between height classes. This implies that the more intelligent child will be found in the small family, and will usually be taller than the majority of all children of the same age, but that family size is the more important influence.

\section{Discussion}

The Tables so far produced show that:

(a) Height, weight, and verbal reasoning scores all tend to decrease as family size increases;

(b) Independently of family size, height and verbal reasoning scores tend to rise and fall in sympathy;

(c) Family size is more closely associated with variation in verbal reasoning scores than height.

An estimate of family size was incorporated into the original survey of heights and weights with a view to finding out whether the known differences in food consumption in households of different sizes affected growth. Nothing very conclusive emerged, except that the diminution in the size of the children with increasing size of the family was due partly to the later age of sexual maturity of children in the larger families.

A facile explanation of the relationship of verbal reasoning scores to family size is that the less intelligent (as assessed by this test) are more fertile. Quite apart from the fact that the measure of family size was not exact and that it did not necessarily connote the ultimate size of family, the use of averages masks the variability that exists within each of the groups tabulated. Table VI gives the percentage frequency distribution of verbal reasoning scores by family size, and shows clearly that, although there are proportionately more children in the upper ranges

TABLE VI

PERCENTAGE FREQUENCY DISTRIBUTIONS OF VERBAL REASONING STANDARDIZED SCORE, BY FAMILY SIZE

\begin{tabular}{|c|c|c|c|c|c|c|c|c|c|}
\hline \multirow{2}{*}{\multicolumn{2}{|c|}{ Group }} & \multirow{3}{*}{$\begin{array}{c}\begin{array}{c}\text { Family } \\
\text { Size } \\
\text { (No. of } \\
\text { Children in } \\
\text { Family) }\end{array} \\
1 \\
2 \\
3 \\
4 \text { or More }\end{array}$} & \multirow{3}{*}{$\begin{array}{c}\begin{array}{c}\text { No. of } \\
\text { Children }\end{array} \\
336 \\
399 \\
202 \\
151\end{array}$} & \multicolumn{6}{|c|}{ Verbal Reasoning Standardized Score } \\
\hline & & & & \multirow{2}{*}{$\begin{array}{c}70-79 \\
9 \cdot 2 \\
10 \cdot 5 \\
15 \cdot 3 \\
15 \cdot 2\end{array}$} & \multirow{2}{*}{$\begin{array}{c}80-89 \\
13 \cdot 3 \\
17 \cdot 5 \\
16.9 \\
17.9\end{array}$} & \multirow{2}{*}{$\begin{array}{c}90-99 \\
27 \cdot 8 \\
23 \cdot 8 \\
23 \cdot 3 \\
31 \cdot 9\end{array}$} & \multirow{2}{*}{$\begin{array}{c}100-109 \\
24 \cdot 4 \\
24 \cdot 3 \\
18 \cdot 3 \\
23 \cdot 8\end{array}$} & \multirow{2}{*}{$\begin{array}{c}110-119 \\
14 \cdot 6 \\
13 \cdot 6 \\
18 \cdot 3 \\
7 \cdot 9 \\
\end{array}$} & \multirow{2}{*}{$\begin{array}{c}120 \text { and Over } \\
10 \cdot 7 \\
10 \cdot 3 \\
7 \cdot 9 \\
3 \cdot 3\end{array}$} \\
\hline & B & & & & & & & & \\
\hline & G & 4 or $\begin{array}{l}1 \\
2 \\
3\end{array}$ & $\begin{array}{l}307 \\
412 \\
196 \\
166\end{array}$ & $\begin{array}{r}6 \cdot 2 \\
5 \cdot 1 \\
6 \cdot 1 \\
12 \cdot 7\end{array}$ & $\begin{array}{l}14 \cdot 0 \\
12 \cdot 7 \\
14 \cdot 8 \\
17 \cdot 4\end{array}$ & $\begin{array}{l}22 \cdot 8 \\
24 \cdot 2 \\
36 \cdot 7 \\
27 \cdot 8\end{array}$ & $\begin{array}{l}27 \cdot 7 \\
29 \cdot 2 \\
23 \cdot 0 \\
25 \cdot 9\end{array}$ & $\begin{array}{r}18 \cdot 9 \\
16 \cdot 7 \\
8 \cdot 7 \\
9 \cdot 6\end{array}$ & $\begin{array}{r}10 \cdot 4 \\
12 \cdot 1 \\
10 \cdot 7 \\
6 \cdot 6\end{array}$ \\
\hline \multirow{2}{*}{ II } & B & $\begin{array}{l}1 \\
2 \\
4 \\
3\end{array}$ & $\begin{array}{l}243 \\
425 \\
201 \\
176 \\
\end{array}$ & $\begin{array}{r}4 \cdot 1 \\
6 \cdot 1 \\
5 \cdot 5 \\
13 \cdot 6 \\
\end{array}$ & $\begin{array}{l}13 \cdot 6 \\
13 \cdot 9 \\
13 \cdot 0 \\
22 \cdot 2\end{array}$ & $\begin{array}{l}26 \cdot 4 \\
21 \cdot 4 \\
25 \cdot 9 \\
22 \cdot 2\end{array}$ & $\begin{array}{l}23 \cdot 9 \\
27 \cdot 3 \\
27 \cdot 3 \\
19 \cdot 9\end{array}$ & $\begin{array}{l}20 \cdot 9 \\
19 \cdot 3 \\
12 \cdot 9 \\
13 \cdot 6\end{array}$ & $\begin{array}{r}11 \cdot 1 \\
12 \cdot 0 \\
15 \cdot 4 \\
8 \cdot 5\end{array}$ \\
\hline & G & $\begin{array}{c}1 \\
2 \\
3 \\
4 \text { or More }\end{array}$ & $\begin{array}{l}244 \\
396 \\
213 \\
192\end{array}$ & $\begin{array}{l}2 \cdot 5 \\
4 \cdot 0 \\
6 \cdot 1 \\
8 \cdot 8\end{array}$ & $\begin{array}{l}10 \cdot 6 \\
10 \cdot 1 \\
13 \cdot 6 \\
20 \cdot 3\end{array}$ & $\begin{array}{l}19 \cdot 3 \\
23 \cdot 3 \\
21 \cdot 6 \\
27 \cdot 7\end{array}$ & $\begin{array}{l}27 \cdot 4 \\
26 \cdot 3 \\
26 \cdot 3 \\
25 \cdot 0\end{array}$ & $\begin{array}{l}22 \cdot 6 \\
19 \cdot 9 \\
20 \cdot 6 \\
11 \cdot 5\end{array}$ & $\begin{array}{r}17 \cdot 6 \\
16 \cdot 4 \\
11 \cdot 8 \\
6 \cdot 7\end{array}$ \\
\hline
\end{tabular}




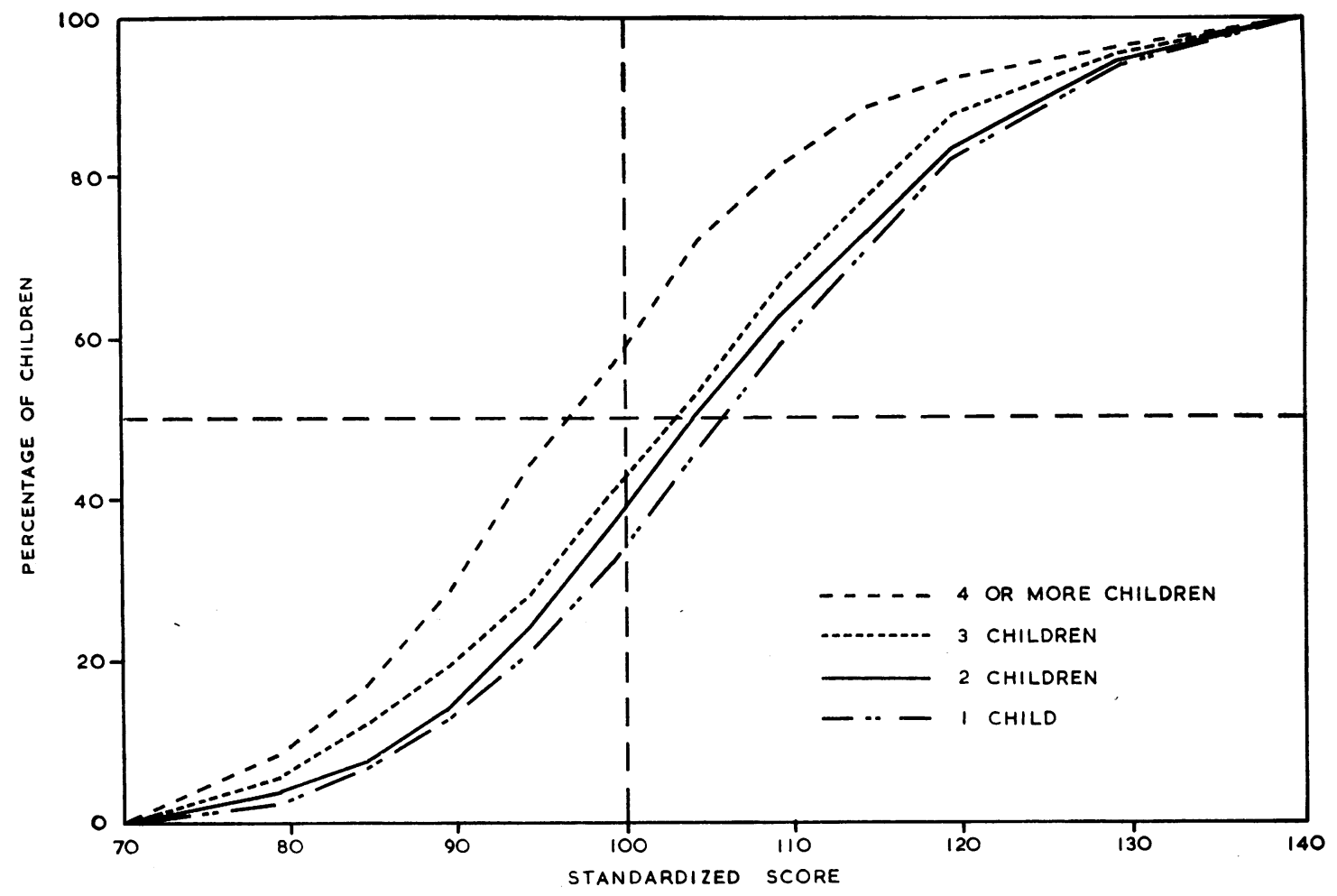

FIG. 1.-Cumulative frequency distributions of verbal reasoning standardized scores, by family size. (Data of Group IIG-Table IV)

of intelligence (scores) in the smaller families and vice versa, there are nevertheless some children at both extremes of the range of intelligence whatever the family size.

A similar pattern is to be seen in Fig. 1, which gives the cumulative frequency distributions (the ogives) of verbal reasoning scores for the different family size classes of Group IIG.

The pattern is repeated in Fig 2 (opposite), which shows the ogives of verbal reasoning scores for the different height classes of the same group.

In all height groups, there are some children with both high and low verbal reasoning scores, but there is a wide divergence between the curves of the shortest and tallest height groups, 60 per cent. of the shortest group being below the (theoretical) mean standardized score of 100 compared with 31 per cent. of the tallest group. Consideration of the two diagrams together shows a more consistent pattern of differences by family size which accords with the analysis of variance.

It was shown in the report on the original survey that, though there was a height and weight gradient with family size, this was partly due to the fact that children in large families tended to mature later physically.

It has been shown elsewhere that children who are physically advanced for their age do in fact score higher in mental ability tests than those who are less mature (Franzblau 1935; Abernethy 1936; Freeman and Flory 1937; Shuttleworth 1939; Boas 1941). More recently Douglas (1960) has reported similar results for a sample of children drawn from all over Great Britain. Thus it would appear that the verbal reasoning test is an assessment of the level of maturity as well as an assessment of basic intellectual potential, an opinion supported by Tanner (1961).

Although placement in secondary schools is based not only on verbal reasoning tests but on attainment tests, teachers' assessments, and the wishes of parents, there is still a degree of separation by size.

Berry and Cowin (1954) have shown that, although there were differences in physical size between 14-year-old boys associated with parents' social class, there were still greater differences 


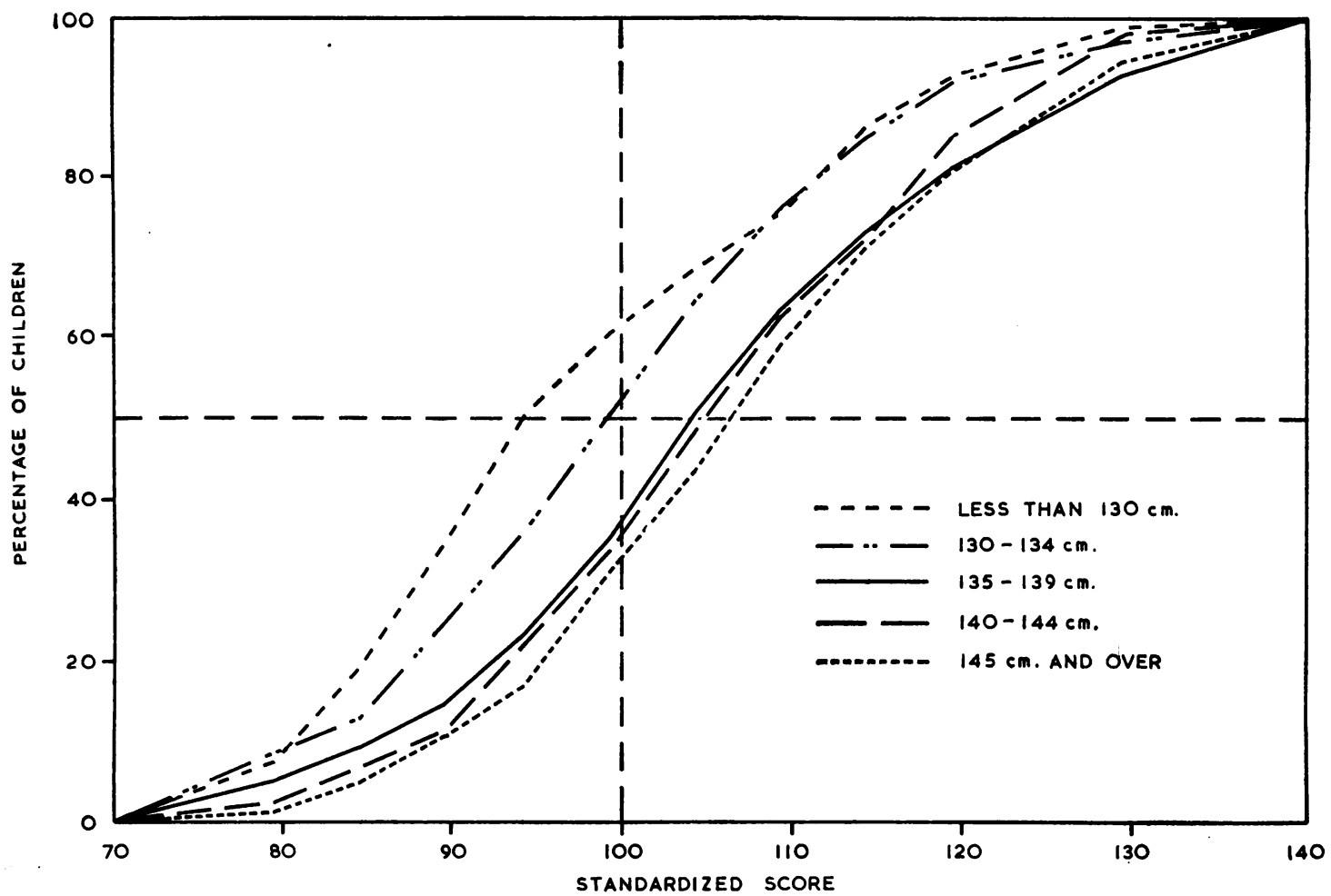

FIG. 2.-Cumulative frequency distrtbutions of verbal reasoning standardized scores, by height. (Data of Group IIG-Table IV)

between grammar and secondary modern school boys whose fathers had the same occupations. Table VII shows the mean heights at standardized ages of pupils at different kinds of secondary school. (These data were drawn from the original survey and related to children in the age range shown and not those whose data have hitherto been analysed.)

TABLE VII

MEAN HEIGHT (cm.), BY TYPE OF SCHOOL AT STATED AGES*

(Figures in brackets show the numbers of children)

\begin{tabular}{|c|c|c|c|c|c|c|c|}
\hline \multirow{2}{*}{$\begin{array}{l}\text { Sex } \quad . \\
\text { Age (yrs) }\end{array}$} & \multirow{2}{*}{$\begin{array}{ccc}\cdot & \cdots & \cdots \\
& \cdots & \cdots\end{array}$} & \multicolumn{3}{|c|}{ Boys } & \multicolumn{3}{|c|}{ Girls } \\
\hline & & $13 \cdot 5$ & $14 \cdot 5$ & $15 \cdot 5$ & $13 \cdot 5$ & $14 \cdot 5$ & $15 \cdot 5$ \\
\hline \multirow{3}{*}{$\begin{array}{c}\text { Type } \\
\text { of } \\
\text { School }\end{array}$} & Grammar & $\begin{array}{l}157 \cdot 5 \\
(171)\end{array}$ & $\begin{array}{l}163 \cdot 8 \\
(148)\end{array}$ & $\begin{array}{l}170 \cdot 1 \\
(152)\end{array}$ & $\begin{array}{l}158 \cdot 1 \\
\text { (129) }\end{array}$ & $\begin{array}{l}160 \cdot 7 \\
(115)\end{array}$ & $\begin{array}{l}160 \cdot 9 \\
(100)\end{array}$ \\
\hline & $\begin{array}{l}\text { Compre- } \\
\text { hensive }\end{array}$ & $\begin{array}{l}55 \cdot 8 \\
195)\end{array}$ & $\begin{array}{l}164 \cdot 1 \\
(138)\end{array}$ & $\begin{array}{r}169 \cdot 0 \\
(67)\end{array}$ & $\begin{array}{l}157 \cdot 4 \\
(186)\end{array}$ & $\begin{array}{l}160 \cdot 2 \\
(156)\end{array}$ & $\begin{array}{r}161 \cdot 6 \\
(72)\end{array}$ \\
\hline & Other & $\begin{array}{l}155.6 \\
(909)\end{array}$ & $\begin{array}{l}163.0 \\
(740)\end{array}$ & $\begin{array}{l}168.5 \\
(339)\end{array}$ & $\begin{array}{l}155.9 \\
(779)\end{array}$ & $\begin{array}{l}158.6 \\
(785)\end{array}$ & $\begin{array}{l}160 \cdot 6 \\
(377)\end{array}$ \\
\hline
\end{tabular}

* Standardized to exact half-years by simple linear interpolation.

The gap in height between pupils at grammar and "other" schools existing at $13 \cdot 5$ years has tended to narrow by 15.5 years; in the case of girls, who mature and reach adult stature earlier than boys, it has virtually disappeared. Some children may have left school at $15 \cdot 5$ years and they may well have been the shorter and/or less intelligent. If the development of physique and intellectual ability do go together, the narrowing of the gap would seem to provide justification for flexibility in school organization and facilities for transfer at $13+$. (In London the basic principles for the provision of secondary education are that no decision at age 11 should be or seem to be final, and that at all stages in a pupil's secondary school career a wide range of appropriate courses should be available, preferably in the same school; the field of recruitment of comprehensive schools overlaps those of the other two groups of schools.)

There are clearly large gaps in our knowledge-it would be interesting to know how the intelligence of children compared at $15+$, whether the gap had 
narrowed, whether such narrowing was greater for girls than for boys, and whether the same pattern(s) held good for the generality of children or only within groups attending the same kind of school. This type of general comparison would require some form of ability test which could make appropriate allowances for differing educational and environmental factors.

One aspect of this complex of factors bearing on intelligence, which has not yet been mentioned, is social class. Keddie (1958) showed that there were differences between the average stature of children from different socio-economic backgrounds, and Tanner (1961) estimated that the difference in height between children of the professional and managerial classes and those of unskilled labourers is currently of the order of $1 \frac{1}{2}-2$ inches at adolescence. It is known from the Census reports of the Registrar General that those in the higher social classes tend to have fewer children. Vernon (1960) showed how the mean intelligence of children varied with the father's occupation-falling as the element of skill lessens. Again it would be facile to argue that, because smaller children tend to be less intelligent and tend to belong to larger families which tend to be of a lower social class, it is the social class element which is the prime cause. As Vernon pointed out, 'there is tremendous overlapping. A few labourers' children will range up to I.Q. $130+$ and a few professional children down to I.Q. 80 or less (in addition to 'freak' defectives)".

It would seem reasonable to suppose that in a large family the parents cannot spend so much time individually on or with their children as in a small one. On the other hand, it is equally clear that in a large family the children have greater opportunities of mixing with other children. A recent report (Stewart, 1962) suggests that family conditions for last-born children may tend to prevent their achieving the level of academic achievement and social initiative reached by the first-born. In any case the birth order of the children who have formed the subject of the present study is not known, and there may well be a differential effect depending upon the place of the child in family. Quite apart from the family background in the educational aspect (hobbies, reading habits, conversational topics, etc.), there is the question of spatial facilities -has the child in the large family the opportunity to read or to make things in peace and quiet before the 11 + examination and to do homework after it? In this connexion it is understood that homework centres are provided in Liverpool for both secondary modern and primary school pupils and that they are to be the subject of an experiment at Stoke-on-Trent.
It must be repeated that the facts and figures discussed did not originate from a planned survey of intelligence and its related factors, but from a gathering together of data from two unrelated sources. It is, therefore, hardly surprising that more questions are raised than are answered. Despite these limitations it was felt that the evidence put together might add to the "meagre knowledge" to which Professor Medawar referred and perhaps lead others to explore some of the avenues shown to exist. Burt urged that "systematically planned inquiries should be carried out by trained psychologists". From what has been said in the foregoing it would seem appropriate to add "and specialists in physical growth" because of the maturity aspect. Physical development in children varies enormously at any given chronological age and the implications of this paper are that, to some extent, intelligence does likewise.

\section{Summary}

Data for some of the school pupils included in the London survey of heights and weights, 1959, was linked with the results of the verbal reasoning test of the junior leaving $(11+)$ examinations of 1959 and 1960.

Mean standardized test scores were found to decrease as family size increased, as had previously found to be the case with physical measurements.

As children in larger families tend to mature later physically, the possibility of a link between physical and mental maturity, and its impact on the results of intelligence testing, is discussed.

The interrelation of intelligence, physique, and family size, and their common association with social class, is also discussed in relation to the possibility of compensating for the effects of environment.

I am grateful to my colleague, Mr. W. F. Houghton, the Education Officer of the London County Council, for making available the results of the verbal reasoning tests and for helpful advice; to Mr. C. W. Shaddick, statistician of the Public Health Department, and to Mr. A. T. Gore and Mr. V. R. Housden of the statistical section.

\section{REFERENCES}

Abernethy, E. M. (1936). Monogr. Soc. Res. Child Developm., 1, No. 7.

Berry, W. T. C., and Cowin. P. J. (1954). Brit. med. J., $1,847$.

Boas, F. (1941). Science, 93, 339.

Burt, C. (1917). "The Distributions and Relations of 
Educational Abilities". London County Council, London.

(1946). "Intelligence and Fertility". Eugenics Society, London.

Douglas, J. W. B. (1960). Communication to Society for the Study of Human Biology.

Franzblau, R. N. (1935). Arch. Psychol. (N.Y.), No. 177.

Freeman, F. N., and Flory, C. D. (1937). Monogr. Soc. Res. Child Developm., 2, No. 2.

Keddie, J. A. G. (1958). Med. Offr., 99, 87, 101.

Kerr, J. (1906). "Annual Report of the Medical Officer of Health". London County Council, London.

Lawley, D. N. (1950). Brit. J. Psychol. (Stat. sect.), 3, 86.

Maxwell, J. (1953). "Social Implications of the 1947 Scottish Mental Survey". University of London Press, Publ. No. 35.

(1958). "Educational and other Aspects of the 1947 Scottish Mental Survey". University of London Press, Publ. No. 41.
Medawar, P. B. (1959). Listener, 62, 1067 (Dec. 17).

Scott, J. A. (1961). "Report on the Heights and Weights (and Other Measurements) of School Pupils in the County of London in 1959". London County Council, London.

Shuttleworth, F. Kay (1939). Monogr. Soc. Res. Child Developm., 4 , No. 3 .

Stewart, M. (1962). "The Success of the First Born Child". Workers Educational Association, London.

Tanner, J. M. (1961). "Education and Physical Growth." University of London Press, London.

Vernon, P. E. (1960). "Intelligence and Attainment Tests". University of London Press, London.

Yates, A., and Pidgeon, D. A. (1957). "Admission to Grammar Schools". National Foundation for Educational Research in England and Wales, Publ. No. 10. Newnes, London.

Yates, F. (1933). J. agric. Science, 23, 108. 